\title{
Stylistics goes to school
}

\section{Ian Cushing}

\begin{abstract}
Stylistics offers a wealth of benefits to English teachers who wish to integrate aspects of language and literature together, and to engage their students in a text-driven, reader-response informed grammar pedagogy. Recently, there has been a growing interest in how stylistics can be re-contextualised to schools, with academics working collaboratively with teachers in the form of teacher workshops, school curriculum reform and classroom-based research. In this paper, I aim to provide a picture of what this work looks like, and argue that it presents an important moment in the history of stylistics, both as a discipline and as a pedagogical method. The re-contextualisation of stylistics to schools has the potential to further validate academic research findings, as well as offering English teachers an enabling and accessible toolkit for teaching about language and literature that is likely to sit comfortably with their own beliefs about the subject. However, there are various logistical and political complexities involved, such as access to training, teacher subject knowledge and teacher attitudes towards linguistics. In light of this, I discuss the design and implementation of a training course about stylistics for teachers, and how participants on these courses have taken that knowledge and actualised it in their own practice. I also present some of the barriers that teachers faced in trying to do so. I argue that stylistics is beneficial for teachers, and the present moment presents an important and potentially fruitful time for the discipline.
\end{abstract}

\section{Introduction}

Numerous scholars have argued for the place of stylistics in schools, as a pedagogical method of teaching about language that invites interpretative responses from young readers (e.g. Carter, 2007; Giovanelli, 2010, 2016b, 2017; Macrae, 2016; McIntyre, 2011). For stylisticans, language is a sociocultural system of meaning that has the capacity to create rich effects in the minds of readers, a view that is reflected in various education policy documents, such as the secondary school National Curriculum for English, in England and Wales (DfE, 2013a, 2013b). In the UK, there is a growing interest amongst academics and teachers as to what stylistics can offer to L1 English teaching, explored in a number of recent studies (e.g. Cushing, 2018; Giovanelli, 2016b, 2017), various workshops for teachers run by academic stylisticians ${ }^{1}$, and partly triggered by changes to GCSE (mandatory qualifications taken at the end secondary school) and A-level (optional post-16 qualifications) specification content towards a literary linguistic leaning. For example, students who take the current AQA A-level in English Language and Literature are required to engage in stylistics, learning about concepts such as foregrounding, world-building, transitivity and narrative theory (AQA, 2016). At GCSE level, students are required to analyse the language of literary texts, by examining an author's structural, lexical and grammatical choices and considering the kinds of effects that these have on a reader. In schools outside of the UK, the influence of meaning-orientated grammars which share some principles with stylistics can be seen in various different forms, deployed as pedagogies that aim to translate complex linguistic frameworks into usable systems and principles for teachers. For example, pedagogical versions of systemic functional linguistics (SFL) and genrebased literacy programmes have a long history in relation to the Australian curriculum (e.g. MackenHorarik, et al., 2015; Rose and Martin, 2012). In the US, principles from functional linguistics are also found in teachers' repertories, in literacy pedagogies such as rhetorical grammar (Kolln and Gray, 2012) and SFL (e.g. Gebhard et al., 2014; Schleppegrell, 2016). A detailed account of these and case studies from other international contexts - can be found in Locke (2010). Whilst such work shares certain premises with stylistics, namely the connection between close textual analysis and reader interpretations, the potential of recent developments in stylistics as pedagogical applications such as Cognitive Grammar, Text World Theory and corpus stylistics - is at a relatively early stage.

\footnotetext{
${ }^{1}$ Workshops on various aspects of stylistics for teachers have been offered by the universities of Aston, Birmingham, Huddersfield, Sheffield, Nottingham and UCL. I would be glad to hear of any other examples and apologise for any omissions.
} 
In addition, the value and nature of pedagogical stylistics in L2 contexts has been well-researched (see for example Burke et al., 2012 and Fogal, 2015).

However, despite the benefits that stylistics offers, there remains a lack of research into how stylistics is re-contextualised from HE to schools and what pedagogical stylistics looks like in the school classroom in L1 contexts (see Carter 2007: 7-10). In this paper, I argue that if a recontextualisation process is to happen successfully, academics should look to working collaboratively with teachers in order to demonstrate the enabling potential of stylistics and what it can do for their own students' understanding of how language works. I discuss my attempt to do this by detailing the design and implementation of a stylistics course for teachers, and presenting data provided by participants who have successfully employed stylistics in their own practice. I also discuss some of the barriers and constraints that teachers face, in particular their own linguistic subject knowledge and mixed attitudes to literary linguistics. In doing so, I hope to show that stylistics offers an enabling pedagogy to English teachers which is in line with National Curriculum requirements and invites interpretative and linguistically systematic responses from young readers. Although the research took place in the UK, I argue that the findings are relevant for an international audience, especially for linguists who are keen to engage collaboratively with teachers, in disseminating research and building teacher-researcher pedagogies.

\section{What does stylistics offer to teachers?}

Stylistics is a hands-on methodology for analysing texts, where learners are encouraged to be active participants in exploring textual meaning and the effects that texts have the capacity to create (e.g. Simpson, 2014; Jeffries and McIntyre, 2010). For the stylistician, meaning construction takes place within socio-cultural contexts and through a combination of text, author and reader(s), where reading is construed as a highly creative activity. Personal responses are valued, but must hold the text to account. Given this wealth of benefits and principles that are likely to sit comfortably with English teachers' beliefs about literature, it is surprising that the word stylistics is rarely used in the English teaching community and does not appear a single time on the current UK English curriculum (DfE, 2013a, 2013b), nor on previous versions. I suggest that the aims of stylistics are in line with aspects of the current secondary school National Curriculum for English, and the kind of contextualized grammar pedagogy which is generally advocated in schools. The National Curriculum stipulates that, amongst other things, students should be taught to:

[know] how language, including figurative language, vocabulary choice, grammar, text structure and organisational features, presents meaning

[study] the effectiveness and impact of the grammatical features of the texts they read

[draw on] new vocabulary and grammatical constructions from their reading and listening, and [use] these consciously in their writing and speech to achieve particular effects (DfE, 2013a: 4 -5)

and

[recognise] the possibility of different responses to a text; [make] an informed personal response that derives from analysis and evaluation of a text (DfE, 2013b: 5).

A stylistics-informed pedagogy would advocate that for students to make 'an informed personal response', they are required to make close reference to the text, reigning in literary interpretations so that they are always conditioned with an understanding of how language works. The next two sections consider stylistics' role in teaching grammar and reader-response in further detail.

\subsection{As a pedagogical grammar}

I focus on grammar here because of its prominent place in the UK curriculum (including statutory grammar tests at primary school and an increased emphasis at GCSE) and continued debates around 
the nature of grammar teaching ${ }^{2}$. In short, the grammar debate has focused on two aspects that are often treated as separate: (1) the purpose and value of grammar on the curriculum, and (2) the most appropriate and effective ways to teach it.

Considering (1), researchers, teachers and policy makers have generally argued that grammar should be taught because it can improve literacy skills. Ostensibly, this would make sense: if you have a heightened awareness of grammatical structures, you are better able to actualise this knowledge into your own writing, or to analyse the writing of others. Yet decades of research have been somewhat inconclusive in validating this. Influential work by Myhill et al. (2012) showed that contextualized grammar teaching can have a positive benefit on students' writing ability and metalinguistic understanding, using resources designed by the research team that drew on rhetorical grammar and principles from stylistics ${ }^{3}$. Considering (2), I would like to suggest that good grammar pedagogy adheres to the following principles:

- Grammar should be taught in the context of authentic texts.

- Students should discuss grammatical structures in reference to their meaning-making capacity and their potential to create effects in the minds of readers.

- Metalanguage should be used as a means of enabling a more systematic analysis.

- Students should be invited to offer interpretations of a text that hold the text to account.

\subsection{As a reader-response theory}

Whiteley and Canning (2017) argue that reader-response research should form an integral component of stylistics, in the sense that textual form and interpretative effects only come into being upon contact with a reader. Readings and interpretations in schools are undoubtedly concerned with real-life readers. And yet, sadly, much English teaching is underpinned by a transmissive pedagogy in which teachers simply project their own 'expert readings' onto their students, which are then assigned as 'correct' responses and regurgitated in assessments. Many scholars are critical of such teacherdominated discussions of literature, where reading is reduced to a 'vehicle for mechanistic outcomes' (Goodwyn, 2012: 224). Such a pedagogy for reading downplays and minimizes the student voice the real-life reader who plays such a crucial role in the construction of meaning. Given this, I suggest that stylistics presents an important way of construing the reading experience and foregrounding the role of the student reader's response. This view of reading is highly relevant to school teachers who wish to challenge a transmissive pedagogy and move towards one that generates 'authentic' responses in the classroom (see Giovanelli and Mason, 2015: 52, who propose a cline of authentic and manufactured reading in order to describe the difference between student and teacher-dominated responses to literature).

\section{Teacher linguistic knowledge and training for teachers}

This section explores linguistic subject knowledge in teachers and the potential impact of this in recontextualising stylistics to schools.

In the UK, the majority of English teachers entering the profession do so from a literature background, where they may not have encountered any work related to linguistics or stylistics and typically have low linguistic subject knowledge (see Blake and Shortis, 2010; Cajkler and Hislam, 2002). Further still, any linguistic content on teacher training courses is likely to be minimal, despite the increased emphasis of grammar on the curriculum. Whilst this is certainly not the case for all teacher training courses - for example, see Giovanelli (2016a) - it is clear that much work needs to be done in preparing pre-service teachers to teach about language, and to develop in-service teachers' subject knowledge. The Integrating English project (www.integratingenglish.com) provides a good example of this, with academic stylisticians working closely with English teachers in providing subject-specific support, an annual symposium and a clear position on the value of integrated

\footnotetext{
2 Those readers looking for a comprehensive account of the history of grammar teaching in different international contexts should consult Hudson and Walmsley (2005), and Locke (2010).

${ }^{3}$ Available for free at: www.socialsciences.exeter.ac.uk/education/research/centres/centreforresearchinwriting/grammar-teacherresources/
} 
language-literature work. The project has also published two reports detailing provision of languageliterature work at post-16 and HE, and transition issues (Clark and Macrae, 2014; Clark et al., 2015).

Attempts to improve teacher knowledge in linguistics are not without difficulties. Many

English teachers are resistant to linguistics, rooted in deep misunderstandings about the subject, with many associating it with rules, standards, technical terms (see Qualifications and Curriculum Authority, 1998 and Watson, 2015) and a threat to their professional identities as 'literature teachers' (Giovanelli 2015: 418). Whilst these negative discourses towards language work may be common, work has also demonstrated that if teachers are given access to training and shown the benefits that linguistic knowledge can bring to their practice, they are more likely to express positive attitudes towards language and adapt their pedagogical decisions accordingly (Giovanelli, 2015; Watson, 2012).

\section{Pedagogical stylistics and the re-contextualisation process}

When stylistics is applied to a classroom setting, it becomes pedagogical stylistics, where its chief aim is to 'sensitize students to language use within the texts chosen for study (Clark and Zyngier, 2003: 341, see also Hall, 2014 and Jeffries and McIntyre, 2011).

Pedagogical stylistics has been the focus of a number of scholars (e.g. Burke, 2010; Carter, 1989; Clark and Zyngier, 2003; Giovanelli, 2010, 2016b, 2017; Short 1996; Zyngier and Fialho, 2010, 2015; Viana and Zyngier, 2017; Widdowson, 1975; Zyngier, 2006; Zyngier and Viana, 2016, amongst others), and the special interest group (PEDSIG) of the Poetics and Linguistics Association. Whilst many studies have discussed the aims and processes of pedagogical stylistics within a university context (e.g. Simpson, 2010; Sotirova, 2016; Zyngier and Fialho, 2010; 2015) and in L2 contexts (e.g. Burke et al., 2012; Fogal, 2015), there is a distinct lack of research related to L1 English teaching in schools ${ }^{4}$. Although McIntyre (2011: 12-14) acknowledges the place of stylistics within A-level English Language, there is little empirical evidence of what this looks like in L1 classroom practice, as is the case for Giovanelli (2010), Macrae (2016), and Mahlberg and Stockwell (2016). It is not my intention to be critical here, for such writing is important in theorising the potential of stylistics in the classroom. But research is needed to evaluate the impact of this potential, and how it transfers to real practice.

When a model of language is re-contextualised to schools, it must be disseminated with a sensitivity to the needs of the practitioners involved. Successful examples of this typically report a collaborative relationship between participants, as demonstrated in work by both Cushing (2018) and Giovanelli (2016b; 2017), who worked closely with teachers in exploring the application of cognitive stylistics in schools, both as a tool for teaching aspects of grammar, and as a model of readerresponse. An important part of both these studies was researchers working collaboratively with teachers, training them in stylistics and co-designing teaching materials specifically to suit the needs of the specific professional context.

Considering re-contextualisation then, the process is apparently simple: stylisticians conduct research which informs the creation of teaching materials, and then observe how students react to those materials. However, in practice, the process is complex and difficult, and I argue that it often relies too heavily on the over-simplified metaphor of STYLISTICS IS AN OBJECT. Construed in this way, stylistics is seen as something that can simply be physically taken and placed into a new setting, without consideration for local needs and concerns. Instead then, I offer STYLISTICS IS A PROCESS as a more socially-situated metaphor that acknowledges the sense of human agency, mediation and negotiation involved in a re-contextualisation process. The use of PROCESS over OBJECT foregrounds the activity of stylistics as something that depends on the involvement of real people with differing needs. In a similar way, Clark (2010) discusses the complexities of re-contextualisation, arguing that it needs to happen in a way that teachers can understand and access it, regardless of their own educational background and knowledge, as well as it being 'compatible' with the remainder of the English curriculum.

Furthermore, innovations in academic research often take a long time to reach schools, and some never do. Even if research does reach teachers, many can be resistant or sceptical to what might

\footnotetext{
${ }^{4}$ Of course, publications such as these are useful for the university practitioner, and indeed, have helped to shape the design of the course I discuss in Section 6 of this paper.
} 
be seen as 'the latest fashion in pedagogic research' (Mahlberg and Stockwell, 2016: 254). I suggest that this resistance can be challenged if academics engage with teachers and demonstrate 'live' the usefulness of stylistics via a course or workshop. The following section outlines one way in which this has happened through training provision at INSTITUTION.

\section{Designing and delivering a course for teachers}

At INSTITUTION, I designed a course for teachers that aimed to take aspects of stylistics and show how they could be adapted for use in secondary school. The course was available at various points throughout the year and attracted between $6-20$ people at a time. Between February 2017 - March 2018, a total of 82 teachers participated. It was delivered at INSTITUTION, but also made available as a course within schools, if departments preferred. I led the course, and, as an academic linguist who also has 6 years' experience of teaching English in schools, I was able to understand teachers' needs in terms of the realities of classroom teaching, and had a thorough awareness of the National Curriculum. This knowledge was of course crucial in designing the course content, which covered:

- An overview of the grammatical content on the secondary National Curriculum for England (see DfE, 2013a; 2013b).

- A rationale and pedagogical principles for teaching grammar in context, and a definition of stylistics.

- Some of the principles of reader-response theory, in how meanings are constructed from a meeting or 'transaction' (Rosenblatt, 1938) between text, author and reader.

- A discussion of foregrounding (e.g. Gibbons and Whiteley, 2018: 15-26), whereby linguistic patterns 'stand out' from others, and our attention is drawn to those parts of the text that the author is signalling is important, explored in reference to a contemporary poem.

- How language has the capacity to build rich, fictional worlds in the minds of readers, based on the cognitive stylistic model of Text World Theory (Werth, 1999; Gavins, 2007) and explored in reference to literary fiction and a creative writing exercise.

- Ways of classifying verb types, based on Halliday's systemic functional linguistics (Halliday and Matthiessen, 2004), and applied to contemporary fiction.

- Critical and creative strategies for literary analysis, based on work by Pope (1995) and applied to imagist poetry.

- How language has the capacity to make us believe in and be persuaded by alternative and fictional states, based on cognitive deixis and a contemporary model of modality (Simpson, 2014) and applied to a charity advert.

- How clause structures and patterns can be understood as 'energy transfer' and 'action chains', as outlined in Cognitive Grammar (Langacker, 2008: 355-357).

Although these may look like theoretical models that are the product of university English departments, the teaching ideas were designed to map on to the grammatical content of the UK National Curriculum and the types of texts that school teachers were familiar with. I argue that it is important to not see these activities as 'watering down' linguistic theory, but adapting theory to suit a different context, which in itself is an important part of the re-contextualisation process. The areas of stylistics were chosen because of their prevalence and topicality in contemporary literary linguistic research, notably cognitive stylistics, and the fact that previous research had demonstrated their usefulness in terms of a pedagogy suitable for schools (e.g. Cushing, 2018; Giovanelli, 2016b, 2017). Many of these aspects of stylistics interpret grammatical structures in conceptual ways, such as how clause structure can be thought of as 'energy transfer' and how discourse unfolds and can be tracked through conceptual spaces, or text worlds. It was felt that highlighting these links between language and conceptual effects was an important strand of pedagogical stylistics, especially given the requirement for students to discuss how texts construct meanings in the minds of readers.

On the course, participants were encouraged to discuss interpretations of texts, modelling the kind of dialogic learning that, in my opinion, is a crucial aspect of pedagogical stylistics. I avoided positioning myself as the 'expert reader', encouraging participants to develop their own responses to texts using different tools from stylistics in enabling ways, with the aim being that this kind of 
pedagogy should be replicated in schools. I am keen to stress that the materials used on the course were not presented as intervention materials in the sense of top-down approaches to 'fixing problems' in teaching, without any respect for the autonomy of the expert practitioner. Instead, they were presented as a springboard for teachers to design their own materials based on their own individual contexts and workplaces. Some of these are discussed in the following section.

\section{Stylistics in the classroom}

I now present some of the data collected from participants in response to the course, and how they had translated this into their own practice. Far from being an empirical study, the data collected is meant as an illustration of teachers' responses rather than conclusive evidence of stylistics 'working' in schools. Classroom-based research is needed to validate some of the points raised here and to examine how teachers actualise stylistics in their own practice (the beginnings of which can be seen in Cushing (2018) and Giovanelli (2016b, 2017).

\subsection{Participants and questionnaire}

Teachers who attended the course were invited to respond to a questionnaire about how the course had impacted upon their practice. A total of 12 participants accepted and were asked about their teaching background, what they understood by the term 'stylistics' and 'grammar in context' and how this related to their own professional beliefs about English teaching. They were then asked to provide examples from their practice where they had successfully used stylistics in the classroom, and what this offered in terms of benefits and constraints. Finally, they were asked about potential difficulties in bringing stylistics into the classroom. Teachers came from a range of professional backgrounds, with some keen to express their identity as a 'literature' or 'language' specialist. For example:

I'm definitely a literature person. I didn't know anything about language before being forced to teach it at A-level, and am slowly coming round to seeing its importance.

I studied German [...], so I studied both literature and how language works. (I went to school in the 80s and 90s, so I was only explicitly taught English grammar through German.) In my teaching, I've always been pigeonholed as a linguist because of this slightly unusual background for an English teacher.

Interestingly, none of the participants identified as a 'stylistician' or 'literary linguist'. As noted, English teaching in schools (and universities) is often viewed in rather compartmental ways, with 'language' and 'literature' as two separate subjects. We can understand this through the metaphor OF ENGLISH STUDIES IS A SERIES OF SEPARATE PARTS. These separate parts can remain disconnected, or be connected through integrated work such as stylistics. However, doing this is not without its problems, as evident in comments which suggest a resistance towards linguistics and about being 'forced' to teach A-level English Language.

\subsection{Overall evaluations}

Responses to the course were positive. For some participants, attending the course clarified some of their thinking about grammar and appeared to 'validate' existing pedagogical approaches:

It confirmed and helped to redefine my own pedagogical approach, as well as helping me develop some new ideas. I am currently developing a scheme of work on Chaucer and am integrating a number of the ideas from the course. Some would have been there anyway, but the course helped me focus these and apply them much more exactly. My knowledge is rusty, but I have found applying grammar in context gives me and my students the ability to articulate our personal response much more clearly.

Although I've always believed that grammar isn't necessarily harder than other aspects of English, the course made me suspect that I've bought into this belief a little. 
However, despite positive personal evaluations, some participants expressed concern about how stylistics would be received amongst their colleagues and students:

I'm going back to teaching GCSE from September and I've been developing the resources for the team's imaginative writing unit to include some stylistics. There's been some debate as our GCSE programme leader says that the students won't cope with it but, largely because of the course, I'm confident that these resources will work.

Comments such as these are particularly revealing about teachers' apprehensive attitudes towards stylistics and language work more broadly, in attempting to make connections across the perceived SEPARATE PARTS of the English curriculum. Teacher confidence in linguistics and a resistance towards language work remains a potential barrier to bringing stylistics into the classroom, as expressed in the comments above and throughout other responses, and discussed in Section 3 of this paper. Greater teacher access to training courses and a re-thinking of linguistic content on teacher training programmes are two ways to challenge this.

\subsection{In practice}

Participants were asked to describe how they had used stylistics in their own teaching, and this section looks at some of the responses to this. It is important to stress that the teaching materials described below were created by the participants. They represent teachers' own thoughts about how best to incorporate language work into their classroom, and are reflective of the unique benefits and constraints their particular classes offered. Participants reported using a range of tools from stylistics in their own teaching (one teacher had even given a whole-school assembly about Text World Theory and reading), and here I outline two aspects that proved particularly popular: foregrounding and transitivity.

\section{Foregrounding}

The concept of foregrounding was explored early in the course and underpinned many of the other activities as a way of thinking about how literary language works. One teacher explained how they had taken the same approach with their classes, talking positively about the enabling nature of foregrounding and the way it could be adapted to suit different age groups, texts and genres:

Foregrounding has a multiplicity of uses. With Year 7, I've found that it gives a nice introduction to the idea of movement and structure in texts. It has also proved useful with Year 10 as a way of looking at the new GCSE English Language 'structure' question'. Foregrounding, and indeed patterns or shifts in what is foregrounded, helps significantly and even students who are usually reluctant are able to contribute ideas.

Another teacher explained their use of foregrounding as a tool for teaching poetry, using a simple trigger question to introduce the concept of textual patterns and linguistic highlighting:

I used the idea of foregrounding with my Year 8 class to teach poetry. I asked a simple question 'what do you notice?' to get students to generate various grammatical patterns in the text. I then introduced parallelism and deviation to them, and they explored their patterns using this system and we discussed as a group. It was a neat way of getting students to think about attention and what (and why) writers want to mark out as important to readers, and it led really nicely into exploratory discussions about meanings in texts.

What strikes me about both of these comments is the way that the teachers talk about the simplicity of foregrounding and the relative ease they were able to employ it in their own practice. Foregrounding

\footnotetext{
${ }^{5}$ The question referred to here is part of the AQA GCSE English Language examination, where students are asked to explore how writers structure texts to generate interest and what reader's attention is focused on. Various teachers commented on the potential of foregrounding theory (and cognitive poetics more broadly) in responding to such a task.
} 
offers a conceptually sound and accessible way of thinking about language and meaning, with data revealing how the concept was used to explore attention, focus and prominence across different literary genres. Many participants commented on how foregrounding had presented a new way of thinking about grammar teaching, where metalanguage was used to help explain and account for the cognitive effects of reading, as opposed to a list of terms and perceived rules. Because foregrounding is a relatively simple concept to grasp, it offers a 'way in' to teaching grammar that leads with interpretations rather than simple feature-spotting. For example:

I have found that things like foregrounding make applying grammar in context easier - it makes more sense to do it that way - and gives me and my students the ability to articulate our personal response much more clearly

I was really taken with the idea of text world theory and foregrounding - it seems to me a really clear way of looking at how texts create meanings and where our interpretations come from

Comments such as these supports the argument that stylistics presents a meaningful and accessible set of pedagogical tools that are particularly useful for the practitioner who perhaps feels resistant or anxious about language and grammar work. Also noteworthy is the use of inclusive language used in the comments above, in referring to group work and facilitating reader-responses in the classroom: $m e$ and my students; we discussed as a group; exploratory discussions; even students who are usually reluctant are able to contribute ideas, all of which challenge the transmissive reading pedagogy criticised in work by Goodwyn (2012), and discussed in Section 2.

\section{Transitivity}

Halliday's system of transitivity was another popular aspect of stylistics explored on the course. Participants found it to be an enabling and useful tool when applied to literary fiction, using it to reveal nuanced meanings in characterisation and helping to yield more stylistically rigorous reader interpretations. For example:

Looking at verb categories was really useful. For example, we looked at Mr Hayward in 'Spies' and how he is controlling, a bully, and passive / aggressive - by looking at verb choice they were easily able to describe how the writer created this, despite the unreliability of the narrator. At A-level we looked at Ken Kesey's portrayal of women and the verb choice was particularly revealing. This combines literary interpretations with specific analysis using correct terminology - all top grade stuff.

One participant talked about combining transitivity analysis with textual intervention during creative writing activities, foregrounding the idea of linguistic experimentation and play as a successful pedagogy. The notion of 'language as choice' is an important principle in the kind of contextualized grammar teaching advocated in recent years (e.g. Myhill 2012), and resonates with the model of pedagogical stylistics presented in the course, and replicated in classrooms:

I used the verb types activity with students during creative writing to show students how they can play with language structure and choices in order to create excitement and suspense in their own writing. We looked at re-writing a text that used lots of material verbs to include cognition verbs, and then explored what the differences were. I have since shared these activities with my department so that we can develop our creative writing schemes to embed grammar based activities into writing.

The fact that this teacher had combined two aspects of stylistics, transitivity and textual intervention, is particularly interesting. During the course, this connection was not made explicit, and so provides a nice example of teachers adapting ideas to suit their own needs, in what I consider to be a fundamental component of the STYLISTICS IS A PROCESS metaphor. 


\subsubsection{Barriers and constraints}

Whilst the comments above are positive and encouraging, caution must be taken with the idea that stylistics can be easily integrated into a teachers' repertoire. Participants were asked about some of the barriers and constraints they faced, with many referring to their own and colleague's subject knowledge as a limiting factor. Responses included a particular emphasis on linguistic subject terminology and the various 'anxious' attitudes towards grammar:

Lack of knowledge in colleagues. Terminology can be confused in students' and teachers' understanding (between functional and formal, as well as such things as conjunctions / adverbials etc). Lack of consistency between schools and within departments (and between departments in schools as well).

Knowledge of grammar among teachers is not strong and I include myself among that number. Confidence is in equal low-measure among teachers and pupils.

I think many colleagues feel nervous about grammar teaching. Most people are still from a literature background - though we are luck at my school in that three of us have experience of teaching language at A-level and that helps.

For me, the following comment is particularly resonant, and reflects the kinds of discourses around the value of language and literary linguistic study from many English practitioners:

As programme leader, I find it's not easy to get staff, who tend to have literary backgrounds, to want to teach language. They often object to teaching something which they haven't explicitly studied themselves when they could be teaching to their expertise. They also perceive grammar as complex and boring for them and for their students.

The polarisation of English studies as 'language' or 'literature' continues to pervade the discipline. In Section 6.1 I offered the metaphor of ENGLISH STUDIES IS A SERIES OF SEPARATE PARTS as a way of describing this. Because stylistics rejects such polarised views, it offers a meaningful pedagogy to teachers who, despite their background and subject specialist identity, believe in a unified vision of English and the benefits that such an approach provides, as evidenced in the comments provided by the participants in this research.

\section{Conclusion and discussion}

Stylistics offers a range of benefits to school teachers who wish to integrate language and literature study, and engage in a text-driven, reader-response informed grammar pedagogy. Yet for some teachers, it is a discipline which remains frustratingly 'distant' and difficult to access. The reasons for this are numerous, but include low funding from schools in providing access to in-service training, a lack of literary linguistic work on many English undergraduate programmes and teacher training, low linguistic subject knowledge amongst many teachers, and misunderstandings about the value of language related work in English.

Although this is not an in-depth study and no broad generalisations can be made, nevertheless I have shown how contemporary stylistics can be re-contextualised to suit the needs of school classrooms, via a training course for teachers. I drew on the metaphor of STYLISTICS IS A PROCESS in order to shape the way that this re-contextualisation process works in practice. The potential of contemporary stylistics as a pedagogy for L1 English in schools remains largely untapped, yet emerging work and interest means that this is beginning to change (e.g. Cushing, 2018; Giovanelli 2016 ; 2017). Future studies are needed to explore the potential of school-based pedagogical stylistics further, especially around the issues of re-contextualisation and developing teachers' linguistic knowledge. Training courses for teachers such as the one described in this paper, along with similar ones at other institutions and the work discussed in Section 3 are innovative in ensuring that stylistics has an applied impact outside HE. It is important that a dissemination model for stylistics is not just a simple 'off-the-shelf' one, but a model where teachers are involved in practical ways, and where 
pedagogical stylistics is demonstrated 'live'. Given the recent surge of interest in school-based stylistics along with changes to the school curriculum, I argue that there has never been a better time for academics to do more to promote the discipline and engage with school teachers in demonstrating the power and potential of literary linguistic work.

\section{References}

AQA (2016) AS and A-Level English Language and Literature. Available at:

$<$ http://www.aqa.org.uk/subjects/english/as-and-a-level/english-language-and-literature-7706-7707> Last accessed 24th December 2017.

Blake J and Shortis T (2010) Who's Prepared to Teach School English? Committee for Linguistics in Education.

Burke M (2010) Why care about pedagogical stylistics? Language and Literature 19(1): 7 -11.

Burke M, Csábi S, Week, L and Zerkowitz, J (eds) (2012) Pedagogical Stylistics: Current Trends in Language, Literature and ELT. London: Bloomsbury.

Cajkler W and Hislam J (2002) Trainee teachers' grammatical knowledge: the tension between public expectations and individual competence. Language Awareness 11(3): 161-177.

Carter R (1989) What is stylistics and why can we teach it in different ways? In: Short M (ed) Reading, Analysing and Teaching Literature. London and New York: Longman, 161-77.

Carter R (2007) Literature and language teaching 1986-2006: a review. International Journal of Applied Linguistics 17 (1): 3-13.

Clark, U. (2010). Grammar in the curriculum for English: What next? Changing English 17 (2): 189200.

Clark B and Macrae A (2014) Lang-Lit from A to BA: Integrating Language and Literature study at school and university. Higher Education Academy. Available at $<$ www.heacademy.ac.uk/knowledgehub/langlit-ba-integrating-language-and-literature-study-school-and-university-0 $>$ Last accessed 24th December 2017.

Clark B, Giovanelli M and Macrae A (2015) Lang-Lit from A to BA: Student backgrounds and first year content. Middlesex University Research Repository, eprints. Available at $<$ http://eprints.mdx.ac.uk/14424/> Last accessed 24th December 2017.

Clark U and Zyngier S (2003) Towards a pedagogical stylistics. Language and Literature 12(4): 339351.

Cushing, I. (2018). 'Suddenly, I am part of the poem': texts as worlds, reader-response and grammar in teaching poetry. English in Education 52(1): 7-19.

DfE (2013a) English Programmes of Study: Key Stage 3. London: DfE.

DfE (2013b) English Literature GCSE Subject Content and Assessment Objectives. London: DfE. 
Fogal G (2015) Pedagogical stylistics in multiple foreign language and second language contexts: a synthesis of empirical research. Language and Literature 24(1): 54-72.

Gavins J (2007) Text World Theory: An Introduction. Edinburgh: Edinburgh University Press.

Gebhard M, Chen I and Britton L (2014) "Miss, nominalization is a nominalization:" English language learners' use of SFL metalanguage and their literacy practices. Linguistics and Education 26: $106-125$.

Gibbons A and Whiteley S (2018) Contemporary Stylistics: Language, Cognition, Interpretation. Edinburgh: Edinburgh University Press.

Giovanelli M (2010) Pedagogical stylistics: a text world theory approach to the teaching of poetry. English in Education 44(3), 214 - 231.

Giovanelli M (2015) Becoming an English language teacher: linguistic knowledge, anxieties and the shifting sense of identity. Language and Education 29(5): 416-429.

Giovanelli M (2016a) Developing beginning teachers' linguistic awareness: issues and practice in Initial Teacher Education. In: Giovanelli M and Clayton D (eds) Knowing About Language: Linguistics and the Secondary English Classroom. London: Routledge, 186-197.

Giovanelli M (2016b) Text world theory as cognitive grammatics: a pedagogical application in the secondary classroom. In: Gavins J and Lahey (eds) World building: Discourse in the Mind. London: Bloomsbury Academic, 109-126.

Giovanelli M (2017) Readers building fictional worlds: visual representations, poetry, and cognition. Literacy 51(1): 26-35.

Giovanelli M and Mason J (2015) "Well I don't feel that": Schemas, worlds and authentic reading in the classroom. English in Education 49(1): 41-55.

Goodwyn A (2012) The status of literature: English teaching and the condition of literature teaching in schools. English in Education 46(3): 212-227.

Hall G (2014) Pedagogical stylistics. In: Burke M (ed.) The Routledge Handbook of Stylistics. New York: Routledge, 2 39-252.

Halliday M and Matthiessen C (2004) Halliday's Introduction to Functional Grammar. London: Arnold.

Hudson R and Walmsley J (2005) The English Patient: English grammar and teaching in the twentieth century. Journal of Linguistics 43(3): 593-622.

Jeffries L and McIntyre D (2010). Stylistics. Cambridge: Cambridge University Press.

Jeffries L and McIntyre D (eds) (2011). Teaching Stylistics. London: Palgrave Macmillan.

Kolln M and Gray L (2012) Rhetorical Grammar: Grammatical Choices, Rhetorical Effects. New York: Longman.

Langacker R (2008) Cognitive Grammar: A Basic Introduction. Oxford: Oxford University Press. 
Locke T (2010) (ed) Beyond the Grammar Wars: A Resource for Teachers and Students on Developing Language Knowledge in the English/Literacy Classroom. London: Routledge.

Macken-Horarik M, Sandiford C, Love K and Unsworth, L (2015) New ways of working with 'grammar in mind' in school English: insights from systemic functional grammatics. Linguistics and Education 31: 145-158.

Macrae A (2016) Stylistics. In: Giovanelli M and Clayton D (eds) Knowing about language: linguistics and the secondary English classroom. London: Routledge, 51-63

Mahlberg M and Stockwell P (2016) Point and CLiC: teaching literature with corpus stylistic tools. In: Burke M, Fialho O and Zyngier S (eds) Scientific Approaches to Literature in Learning Environments. Amsterdam: John Benjamins, 251-267.

McIntyre D (2011) The place of stylistics in the English curriculum. In Jeffries L and McIntyre D (eds) Teaching Stylistics. London: Palgrave Macmillan, 9-29.

Myhill D, Jones S, Lines H and Watson A (2012) Re-thinking grammar: the impact of embedded grammar teaching on students' writing and students' metalinguistic understanding. Research Papers in Education 27 (2): 139-166.

Pope R (1995) Textual Intervention: Creative and Critical Strategies for Literary Studies. Oxon: Routledge.

Qualifications and Curriculum Authority (QCA) (1998) The grammar papers. London: QCA.

Rose D and Martin J (2012) Learning to Write, Reading to Learn: Genre, Knowledge and Pedagogy in the Sydney School. London and Oakville: Equinox.

Rosenblatt L (1938) Literature as Exploration. New York: Appleton Century Crofts.

Schleppegrell M (2016) Content-based language teaching with functional grammar in the elementary school. Language Teaching (49): 116-128

Simpson P (2014) Stylistics: A Resource Book for Students. London: Routledge.

Simpson P (2010) Pedagogical stylistics and literary evaluation. Journal of Literary Studies 15(3-4): $510-528$.

Short M (1996) Stylistics upside down: using stylistic analysis in the teaching of language and literature. In: Carter, R. and McRae, J (eds) Language, Literature and the Learner Creative Classroom Practice. Harlow: Longman, 41-64.

Sotirova V (2016) Empirical stylistics as a learning and research tool in the study of narrative viewpoint. In: Burke, M., Fialho, O. and Zyngier, S (eds) Scientific Approaches to Literature in Learning Environments. Amsterdam: John Benjamins, 1-16.

Viana V \& Zyngier S (2017) Exploring new territories in pedagogical stylistics: an investigation of high-school EFL students' assessments. Language and Literature 26(4): 300-322.

Watson A (2012) Navigating the 'pit of doom': affective responses to teaching 'grammar'. English in 
Education 46 (1): 22-37.

Watson A (2015) Conceptualisations of 'grammar teaching': L1 English teachers' beliefs about teaching grammar for writing. Language Awareness 24 (1): 1-14.

Werth P (1999) Text Worlds: Representing Conceptual Space in Discourse. London: Longman.

Whiteley S and Canning P (2017) Reader response research in stylistics. Language and Literature 26(2): 71-87.

Widdowson H (1975) Stylistics and the Teaching of Literature. London: Longman

Zyngier S (2006) Stylistics: pedagogical applications. In: Brown, K (ed) Encyclopedia of Language and Linguistics. Oxford: Elsevier, 226-232.

Zyngier S and Fialho O (2010) Pedagogical stylistics, literary awareness and empowerment: a critical perspective. Language and Literature 19(1): 13-33.

Zyngier S and Fialho O (2015) Pedagogical Stylistics. In: Sotirova V (ed) The Bloomsbury Companion to Stylistics. London: Bloomsbury, 208-230.

Zyngier S and Viana V (2016) Literary awareness in a high-school EFL learning environment: an empirical evaluation. In: Burke M, Fialho O \& Zyngier S (eds) Scientific Approaches to Literature in Learning Environments. Amsterdam: John Benjamins. 